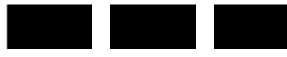 \\ $\square \square \square$ \\ THE WILLIAM DAVIDSON INSTITUTE \\ AT THE UNIVERSITY OF MICHIGAN
}

\section{Media Coverage \& Charitable Giving}

\section{After the 2004 Tsunami}

\author{
By: Philip Brown and Jessica Minty
}

William Davidson Institute Working Paper Number 855

December 2006 


\title{
Media Coverage and Charitable Giving After the 2004 Tsunami
}

\author{
Philip H. Brown ${ }^{\mathrm{a}, \mathrm{b},{ }^{*}}$, Jessica H. Minty ${ }^{\mathrm{c}}$ \\ ${ }^{a}$ Colby College, 5246 Mayflower Hill, Waterville, ME 04901, United States \\ ${ }^{\mathrm{b}}$ International Food Policy Research Institute, 2033 K. St., NW, Washington, D.C. 20006, United States \\ ${ }^{c}$ Analysis Group, 111 Huntington Ave., Boston, MA 02199, United States
}

December 2006

\begin{abstract}
Media coverage of humanitarian crises is widely believed to influence charitable giving, yet this assertion has received little empirical scrutiny. Using Internet donations after the 2004 tsunami as a case study, we show that media coverage of disasters has a dramatic impact on donations to relief agencies, with an additional minute of nightly news coverage increasing donations by 0.036 standard deviations from the mean, or $13.2 \%$ of the average daily donation for the typical relief agency. Similarly, an additional 700-word story in the New York Times or Wall Street Journal raises donations by $18.2 \%$ of the daily average. These results are robust to controls for the timing of news coverage and tax considerations. We repeat the analysis using instrumental variables to account for endogeneity bias, and the estimates are unchanged. However, we also find that the effect of news coverage varies considerably by relief agency.
\end{abstract}

JEL classification: O19, L31, L82

Keywords: Charitable giving; Media; Disasters; Tsunami; Southeast Asia

\footnotetext{
* Corresponding author. Tel.: +1 207859 5246; fax: +1 2078595229

E-mail addresses: phbrown@colby.edu (P.H. Brown); jminty@analysisgroup.com (J.H. Minty)
} 


\section{INTRODUCTION}

Early research into the economics of private giving to charitable organizations classifies the primary motivation for giving as either fostering the provision of public goods or increasing one's private consumption. The "public goods" model is exemplified by donors who give based on the anticipated return in some form of public good (Warr 1982; Roberts 1984; Bergstrom et al. 1986); examples from the literature range from public parks that the donor may frequent to medical research that may benefit the donor at some future time. By contrast, the "private consumption" model arises when donors derive utility from the act of giving, either because the well-being of others enters their own utility functions directly or because the public approval associated with giving benefits the donor (Arrow 1972; Steinberg 1987). For example, conspicuous donations may signal wealth, thereby enabling donors to interact with individuals in higher socioeconomic strata (Glazer and Konrad 1996). However, individuals may receive a "warm glow" from making charitable contributions (Andreoni 1989, 1990) even when their donations displace those of other donors, when there are no direct social benefits to donors, and when the beneficiaries of charitable giving are far away.

Rose-Ackerman $(1982,1996)$ posits that some individuals derive utility from charitable programs only if they "buy in," i.e., if they personally donate. Complementary research in this area suggests that the utility gains from making charitable donations depend critically on the behavior of other donors. For example, Duncan (2004) proposes that some donors may engage in "impact philanthropy" in which individuals make charitable gifts only if their contributions represent a large proportion of the total received by a charitable organization. At the other extreme, Sugden (1984) suggests that individuals have a distaste for freeriding, and hence donate to charitable organizations if others in their peer group have also donated. In this "commitment" model, individuals also believe that they should donate at least as much as members of the reference group.

Regardless of whether motivated by public goods or private consumption, the majority of American households contribute to charitable causes. In 2000, for example, $69 \%$ of U.S. households made charitable donations, with the average contributing household donating $\$ 1,942$ (Steinberg and Wilhelm 2003). Moreover, both the beneficiaries of charitable giving and the level of donations are influenced by world events, as evidenced by the $\$ 2.4$ billion in donations made to the victims of the 11 September 2001 terrorist attacks, by the $\$ 1.6$ billion raised by U.S. 
charities for disaster relief after the 26 December 2004 tsunami, and by the $\$ 3.3$ billion in cash raised by U.S. charities for disaster relief after Hurricane Katrina. These striking examples of generosity coincided with highly-concentrated media coverage in the weeks following the disasters, suggesting a kind of "CNN effect" for charitable giving (Robinson 2002).

Certainly, relief workers have witnessed the link between media coverage and donations that are used to fund daily operations. For example, private donations to relief agencies during the early stages of the Rwandan genocide in 1994 had been sufficient to support approximately one million displaced Rwandans, but after the tribulations of O.J. Simpson and Tanya Harding eclipsed Rwanda in international news, funding for relief activities began to decline. The perception among many aid workers in the camps for Rwandan refugees (including one of the authors) was that the public had turned its back on the crises, with potentially dire consequences. ${ }^{1}$

Yet while anecdotal evidence abounds, few studies have systematically assessed the relationship between media coverage and the behavior of private donors, and those that do suffer from important analytical shortcomings. For example, an analysis undertaken by the Institute for Philanthropy finds that 14 of 15 surveyed British philanthropists believe that the media has the power to encourage private giving, with 11 of the 15 being inspired by the media to make charitable donations themselves (Breeze 2005). Similarly, Olsen, Cartenson, and Høyen (2003) find a high correlation between the total number of relevant articles in western newspapers and the total amount of humanitarian assistance allocated to victims of the flooding in Mozambique in 2000 and the cyclone in eastern India in 1999. Unfortunately, neither sample is large enough to make generalizations, nor is there any attempt to quantify the magnitude of the causal relationship.

This study thus assesses the effect of media coverage on donations to relief agencies in the aftermath of the 26 December 2004 tsunami, an ideal case study because relief agencies concentrated their efforts on tsunami victims for several months, suggesting that donations to relief agencies were in fact donations to tsunami relief. Specifically, we consider the effects of reports on three U.S. nightly network news broadcasts and articles in two prominent newspapers

\footnotetext{
${ }^{1}$ Oxfam Canada incorporated this perception in a highly successful advertisement in nationally-circulated newspapers. A large headline shouted, "O.J. SIMPSON LIMITED TO TEN VISITORS A DAY.” Below, in much smaller print, the text read, "In other news: "500,000 Rwandan slaughtered. Another half million fighting for lives in refugee camps."
} 
on private donations to eight U.S. relief agencies. To minimize recall error and to eliminate the time lag between when news reports are seen or read and when donations are received by relief agencies, we focus exclusively on donations made via the Internet, which accounted for roughly half of the total value of donations to tsunami relief made by individuals (El Nasser 2005). In the empirical analysis, we control for donor fatigue, tax incentives, and agency-specific effects to better isolate the effect of media coverage. Finally, to alleviate concerns of omitted variable bias associated with other forms of reporting and fund-raising and concerns of simultaneity associated with news coverage of the charitable response, we use media coverage of the Iraq war and casualties among U.S. military personnel to instrument for media coverage of the tsunami.

We find that an additional minute of network television news coverage increases a given day's donations by 0.036 standard deviations from the mean, or $13.2 \%$ for the average agency. One additional story in the New York Times or the Wall Street Journal increases a given day's donations by 0.050 standard deviations from the mean, or $18.2 \%$ for the average agency. Results are similar using instrumental variables, underscoring the robustness of the estimates. Additionally, the marginal effect of media coverage differs considerably by agency, with some agencies seeing donations rise dramatically with additional media coverage, while others see donations hold steady or even decline. Finally, we find considerable evidence for declining donations associated with donor fatigue as well as evidence for the effectiveness of tax incentives in increasing donations.

The remainder of this paper is organized as follows: Section II provides details about the tsunami disaster and the media coverage that ensued; Section III describes the data and variables used; Section IV describes the empirical specification and identification; Section V provides the results of this study; and Section VI concludes.

\section{THE TSUNAMI, THE MEDIA, AND CHARITABLE GIVING}

This 26 December 2004 Sumatra-Andaman earthquake off the northwest coast of Sumatra triggered a devastating tsunami that spread across the Indian Ocean, inundating coastal communities and claiming victims in Indonesia, Sri Lanka, India, Thailand, Somalia, Myanmar, the Maldives, Malaysia, Tanzania, Seychelles, Bangladesh, South Africa, Yemen, and Kenya. According to UN Statistics, 229,866 people were either killed or listed as missing (UN Office of 
the Special Envoy for Tsunami Recovery 2005), rendering the tsunami one of the deadliest natural disasters in modern history.

With Congress in recess and many firms operating on reduced staffs, the tsunami had little competition in the U.S. news during the last week of 2004. Moreover, empirical evidence reveals that media outlets allocate disproportionately more attention to unanticipated crises than to ongoing troubles, particularly when such crises are easily explained from a scientific, social, or political perspective (Wynter 2005). Finally, a number of westerners were killed in the deluge, potentially raising demand for media coverage (CARMA International 2005). Thus, the tsunami disaster encouraged an unprecedented media response. For example, CNN deployed over 80 anchors, correspondents, and producers to provide 24-hour coverage of relief efforts. Similarly, the tsunami dominated the front page of the New York Times, garnering over half of the articles on the front page in the week following the disaster, and Time, Newsweek, U.S. News and World Report, The Economist, and numerous other news magazines featured the tsunami and recovery efforts in multiple cover stories. Indeed, the tsunami dominated worldwide media attention well into January, 2005, much longer than any natural disaster in modern history (Wynter 2005).

Private donations to relief agencies were equally unprecedented. For example, Catholic Relief Services reported that it raised more than $\$ 1$ million in under three days, a record for the group (Slavin 2004). While Save the Children USA typically receives several hundred thousand dollars in the month following a disaster, the agency received \$6 million in donations in the first four days following the tsunami (Strom 2005). Lutheran World Relief raised more money in one week than it typically does in one year (Cooperman and Salmon 2005). Indeed, an Associated Press poll revealed that $30 \%$ of American households had donated to the relief efforts within two weeks of the disaster (E1 Nasser 2005). All told, U.S. charities received approximately $\$ 1.6$ billion in private donations for the purposes of tsunami relief (Wallace and Wilhelm 2006).

At least five phenomena may have encouraged this high level of giving. First, the crisis fell at a time of year when many Americans celebrate holidays that emphasize compassion and giving, perhaps fostering the "warm glow" associated with charitable giving (Falk 2004). Second, the beaches of Southeast Asia are familiar to American tourists who have visited in increasing numbers in recent decades (Hall and Page 2000). Third, tax incentives have been shown to motivate charitable giving (e.g., Clotfelter 1985; Kingma 1989; Slemrod 1989; Auten, Sieg, and Clotfelter 2002; Green and McClelland 2002), including giving to international relief 
and development organizations (Ribar and Wilhelm 1995). Tax considerations may have been especially important in charitable contributions after the tsunami because the disaster occurred just five days before the traditional December 31 deadline for 2004 tax deductions and because the Tsunami Disaster Aid Tax Relief Act extended the deadline for charitable contributions for tsunami relief until January 31. Fourth, technology facilitated giving, with approximately half of all donations made online (El Nasser 2005). For example, Internet sites such as Google and Amazon.com added links to charities on their own websites, the latter raising \$2.5 million for the Red Cross in 24 hours (Slavin 2004). Finally, extraordinary treatment of the disaster by the media may have prompted extraordinary donations by Americans, particularly in the context of Rose-Ackerman's (1982, 1996) “buy in” model of giving coupled with Sugden's (1986) "commitment" model, whereby individuals donate because they feel compelled to help and because their friends and colleagues have also donated.

Whatever the underlying motivation, trends in donations closely tracked trends in media coverage of the tsunami, suggesting that the media strongly influenced private giving to relief agencies. Media coverage reached a crescendo on 30 December and donations to relief agencies peaked one day later (Figure 1). A second peak in media coverage occurred on 4 January (nine days after the tsunami) following two minor aftershocks and Secretary of State Colin Powell's visit to the affected region (Figure $2^{2}$ ); donations remained high through this period, and both media coverage and donations fell slowly thereafter. A second spike in donations occurred on 31 January (36 days after the tsunami), when 2004 tax deductions for donations to tsunami donations expired. Subsequent peaks in media coverage included 1 February (when President Bill Clinton was named special envoy to South Asia and the custody battle over "Baby 81" began), 19 February (when Presidents George H.W. Bush and Clinton toured affected countries), 24 February (when photographs of the tsunami taken by Canadian vacationers who subsequently drowned were released ${ }^{3}$ ), 8 March (when Clinton and Bush briefed President George W. Bush on the disaster), and 26 March (the three month anniversary of the tsunami, when the media spotlighted recovery and reconstruction). Media coverage peaked a final time on 28 March,

\footnotetext{
${ }^{2}$ Note that the scales in the two figures are different to better highlight small changes after 21 days.

${ }^{3}$ CAMRA International (2005) notes that the comparatively small number of western victims of the tsunami received a disproportionate share of media attention
} 
when a magnitude 8.7 earthquake occurred close to the epicenter of the December 2004 Sumatra-Andaman earthquake.

\section{DATA AND VARIABLES}

In analyzing the relationship between media coverage of the 2004 tsunami and donations to relief agencies, this study employs daily donations made via each agency's web site. Focusing on online giving minimizes the lag between when a donor observes a news item and when his or her donation is recorded by the recipient agency. Equally importantly, computerized records eliminate concerns of recall error. Finally, online donations accounted for approximately half of all donations for tsunami relief (El Nasser 2005), suggesting that they are a very good indicator of donations to relief agencies more generally.

Three dozen U.S. charities that provided relief to tsunami victims were asked to share their daily receipts from Internet sources for the purpose of this research. Eight agreed to participate in this study, including Catholic Relief Services, CARE USA, Mercy Corps, SurfAid International, and four others who asked to remain anonymous. Five of the eight relief agencies included in the study are among the nation's largest nonprofit groups by private funding (Hall, Kerkman, and Moore 2005). Two are among the ten largest charitable organizations and three have religious affiliations. All eight organizations receive donations from across the United States.

Summary statistics for donations during the 100 days following the tsunami are presented in Table 1. The mean value of daily donations during the study period was $\$ 72,583$. The value of donations varies considerably by agency, however, reflected by the standard deviation of $\$ 265,802$; the smallest organization (Agency 1) averaged $\$ 172$ per day in donations while the largest (Agency 8) averaged $\$ 175,339$. Four agencies received over $\$ 100,000$ on average each day, but only three of the agencies received donations every day during this period. One agency received gifts in excess of $\$ 3,000,000$ on 31 December 2004.

Most agencies recorded donations each day between 26 December 2004 and 5 April 2005. However, Agencies 4 and 8 do not report Internet donations made on weekends. Agency 7 was not equipped to receive web donations until 21 January, reducing the number of observations to 71 for that agency. Finally, Agency 5 is missing three days of observations because Internet 
donations overwhelmed their system, crashing their server. We thus record 714 observations for donations over the study period.

Media coverage is first measured by the number of minutes of tsunami-related reporting on each of the three largest evening news broadcasts. According to the Pew Center for the People and the Press (2004), 34\% of Americans regularly watch the nightly news on one of the three major broadcast networks, making the nightly news among the most common sources for information. The mean number of minutes of tsunami coverage per broadcast of $A B C$ World News Tonight, the CBS Evening News, and NBC Nightly News during the study period are 1.88, 1.52, and 2.23 minutes, respectively, representing a significant proportion of the 18.5 minute broadcasts (which typically also include between eight and nine minutes of commercials). The standard deviations of these broadcasts are 4.02, 3.17, and 4.11 minutes, respectively, indicating that coverage varies considerably over the study period. Tsunami coverage within each broadcast is similar for all three programs, with simple correlations of between 0.66 (ABC and $\mathrm{CBS}$ ) and 0.83 (CBS and NBC). ABC allocated its entire broadcast to the tsunami on 2 January. For CBS, coverage peaked at 12.7 minutes on January 1. For NBC, coverage peaked at 14.8 minutes on January 8 . On each of these days, more than half the program was devoted to tsunami coverage. Both $\mathrm{ABC}$ and $\mathrm{CBS}$ occasionally preempted nightly news broadcasts for sports events, but NBC aired its program every day.

Media coverage is also measured by tsunami-related articles published in major newspapers, of which $42 \%$ of Americans report being regular readers (Pew Center for the People and the Press 2004). Specifically, we consider the word counts of articles appearing in the New York Times and the Wall Street Journal, two of the largest U.S. newspapers by both circulation and subscription (Newspaper Association of America 2006). Word counts in articles pertaining to the tsunami closely mirror time allocated to the tsunami in nightly news broadcasts (Figure 3).

The New York Times averaged 1,792 words in articles pertaining to the tsunami during the study period, approximately 2.6 articles of average length. The Wall Street Journal averaged 2,342 words per day, or 3.3 articles of average length. Word counts of tsunami coverage in the New York Times are highly correlated with those in the Wall Street Journal, with a simple correlation of 0.82 , suggesting that the papers were similarly focused on the disaster during this period. However, the New York Times is published daily while the Wall Street Journal is not 
published on weekends or holidays, and as such, there are fewer observations for the Wall Street Journal than for the New York Times.

\section{EMPIRICAL SPECIFICATION AND IDENTIFICATION}

This paper assesses the causal effect of daily media coverage of the 2004 tsunami on donations to eight U.S.-based relief agencies. Because Internet donations are made and recorded on the same date, using this measure precisely captures the time of giving. If, instead, total donations from all sources were included, it is impossible to discern the timing of the gift and hence the impact of media coverage on donations.

Giving typically peaks immediately following a major disaster and recedes gradually over the weeks that follow (Wynter 2005). This phenomenon is known as "donor fatigue," a state in which donors have already exhausted their resources or in which they grow complacent about appeals for charitable gifts, leading to a diminished public response. The gradual decline in donations is seen clearly in Figure 2. Tax incentives may also affect daily donations independent of media coverage (Clotfelter 1985; Kingma 1989; Slemrod 1989; Auten, Sieg, and Clotfelter 2002; Green and McClelland 2002) as evidenced by the two spikes in charitable giving on 31 December 2004 and 31 January 2005 (Figures 1 and 2).

As noted above, the eight agencies represent the broad spectrum of non-profit organizations offering assistance to tsunami victims, and their daily receipts vary considerably. To account for this variation and to make comparisons across agencies possible, we calculate zscores for each agency's collections on each day; the z-score is defined as the number of standard deviations from the mean across the period of study.

Furthermore, five of the eight agencies included in the study received no donations on at least one day during the study period. Indeed, 118 of the observed 714 daily Internet donations for a given relief agency are zero, suggesting the existence of a corner solution response. Because of censoring at zero, ordinary least squares is an inconsistent estimator. To circumvent this problem, the causal effect of media coverage on donations is estimated via a tobit model:

$$
D O N_{i, t}=\max \left(0, \beta_{1} M E D I A_{t}+\mathbf{X}_{i, t} \beta_{2}+u_{i, t}\right)
$$

where $D O N_{i, t}$ is Internet donations received by agency $i$ on day $t$. $M E D I A_{t}$ is the media coverage of the tsunami and recovery efforts on day $t$, measured either as nightly news reporting on the three largest networks or as word counts in the New York Times and the Wall Street Journal. X 
is a vector that includes the log number of days since the tsunami to account for donor fatigue, a dummy for 31 January 2004 to account for tax incentives associated with charitable contributions for tsunami relief, and a series of dummies for each relief agency. The error term is assumed to follow a normal distribution such that $u \sim N\left(0, \sigma^{2}\right)$.

Measurement error, simultaneity, and omitted variables each potentially bias the estimated effect of media coverage on donations. However, measurement error in media coverage is unlikely as the electronic databases maintain precise figures on the timing of news broadcasts and the word counts of newspaper articles. Any measurement error that does exist is unlikely to be systematic, leading simply to attenuation bias. Simultaneity bias may be more problematic, however. For example, approximately $2.1 \%$ of the tsunami-related articles published in the Wall Street Journal and 1.4\% of those published in the New York Times focused on the magnitude and form of the response by private donors, suggesting reverse causality in a small number of cases.

Omitted variable bias is also potentially problematic. First, other media coverage of the tsunami is likely to influence giving; such coverage may include articles in other newspapers and news broadcasts on other networks, special reports, television talk shows, news magazines and other periodicals, Internet news, and radio news. Second, several of the relief agencies included in this study solicited donations for tsunami victims via advertising and direct mail campaigns. Third, the efforts of some relief agencies were noted in the media, often including instructions for donating (see, for example, Strom 2004). Each of these may result in increased Internet donations, leading to upward-biased estimates of the estimated effect of television and newspaper coverage.

Fortunately, biases induced by measurement error, simultaneity, and omitted variables may be addressed using instrumental variables in a tobit framework. Appropriate instrumental variables are exogenous determinants of daily media coverage of the tsunami that do not correlate with the error term in Equation 1. Dramatic news has been shown to crowd out reporting on disasters (Eldridge 2005), so developments in the Iraq war may influence media coverage of the tsunami. Two different instrumental variables are thus separately employed in this analysis - media coverage of the Iraq war and the number of casualties among U.S. military personnel each day in Iraq. Both are plausibly exogenous to donations to relief agencies as none of the eight agencies worked in Iraq during the period of study. Daily media coverage of the Iraq 
war is measured by total word counts in the New York Times and Wall Street Journal for newspaper coverage and by minutes on the three nightly news broadcasts for television coverage. Information on U.S. military casualties in Iraq is based on U.S. Department of Defense statistics.

A final endogeneity concern arises if the eight relief agencies included in the study are not representative of agencies involved in tsunami relief more generally. If compiling daily records of Internet donations is costly, for example, then the eight agencies that provided data are likely to be either large enough to dedicate staff time to data collection or to be efficient enough that data collection is not costly. Given that the eight agencies differ by size, focus, religious affiliation, and other characteristics and that virtually all relief agencies track Internet giving electronically, we find either possibility unlikely. In addition, virtually all of the agencies that worked in the affected areas accepted online donations and all eight organizations fall under the purview of the United Nations Office for the Coordination of Humanitarian Affairs. Still, we cannot rule out the possibility that the eight agencies included in the study are not fully representative of all relief agencies.

\section{RESULTS}

Table 2 describes the effect of nightly news coverage of the December 2004 tsunami by the major broadcast networks on private donations to eight relief agencies in the 100 days immediately following the tsunami using tobit estimation. The tobit model accounts for the 118 observations in which daily donations are censored at 0 . The dependent variable is the z-score of donations to facilitate comparisons across agencies; coefficients are thus interpreted in terms of standard deviations from the mean donation of $\$ 72,583.3$ during the study period. Columns 2 through 4 show the effect of additional time allocated to coverage of the disaster on $A B C$ World News Tonight, the CBS Evening News, and NBC Nightly News, respectively, in minutes. Column 1 aggregates the three broadcasts into a total number of minutes. Heteroskedasticity-robust standard errors are reported.

Both media coverage and the response of individual donors to relief agencies decay as days, weeks, and months pass, as the images become less shocking, and as individual givers experience donor fatigue. To account for these nonlinear time trends, the log number of days since the tsunami struck is included as an additional regressor. In each of the four specifications, the point estimate is negative and significantly different from zero at the $1 \%$ significance level. 
Total donations to the eight agencies on the tenth day after the tsunami are predicted to fall by 0.037 standard deviations from the mean (13.5\%) from those received on the ninth day, ${ }^{4}$ while donations on the fiftieth day are predicted to fall by 0.008 standard deviations $(2.9 \%)$ from those received on the forty-ninth day. The extended tax deadline also produced a dramatic - if very short - spike in donations (Figure 2). Results show that donations rose by approximately 0.60 standard deviations from the mean (219.7\%) during the last day of January 2005, an effect that is significant at the $1 \%$ level. Agency 1 received fewer donations via the Internet than any of the other relief agencies included in the study. Although Agency 8 is smaller than many of the other agencies, it receives a high share of its private donations via the Internet, a fact that is reflected in the large coefficient on that dummy variable. Agencies 2,3,5,6, and 7 receive significantly larger Internet donations than Agency 1.

One additional minute of total news coverage increases donations by 0.036 standard deviations from the mean, raising the average daily private donation by $12.8 \%$, significant at the $1 \%$ level. An additional minute of relevant coverage on ABC World News Tonight increases donations by 0.084 standard deviations, or $30.8 \%$. An additional minute of coverage on the CBS Evening News or NBC Nightly News increases donations by 0.060 standard deviations (22.0\%) and by 0.065 standard deviations (23.8\%), respectively. All of these estimated coefficients are larger than those for total nightly news coverage, although this reflects the very high correlation of minutes allocated to tsunami coverage among the three largest networks.

Table 3 shows the effect of daily newspaper coverage of the 2004 tsunami on private donations to relief agencies, also using tobit analysis. Columns 2 and 3 report the effect of additional articles in the New York Times and the Wall Street Journal, respectively, measured in 100-word units. The smaller sample size for Wall Street Journal articles reflects the fact that this newspaper is not published on weekends or holidays. The total number of words in tsunamirelated stories from the two sources is added together in Column 1.

Increasing relevant coverage by 100 words in the New York Times raises donations to relief agencies by 0.010 standard deviations from the mean, or $3.5 \%$. An additional 100 words in the Wall Street Journal raise donations by 0.140 standard deviations, or $5.0 \%$. As with television news coverage, the estimated effect of total word counts is smaller than that of either

${ }^{4}-0.351 \times(\ln 10-\ln 9)=-0.0369$ 
the New York Times or the Wall Street Journal alone, reflecting the fact that coverage among print media are highly correlated. One hundred additional total words increase donations to relief agencies by 0.007 standard deviations from the mean, or 2.6\%. An additional story of 700 words, an average among major daily newspaper, raises donations by $18.2 \%$. These results are all significant at the $1 \%$ level. In addition, the effects of passing time and the tax extension are very similar to the estimated coefficients calculated when assessing the impact of television coverage.

While the above results are robust across specifications, endogeneity concerns remain. As noted in Section IV, both simultaneity and omitted variable bias may be problematic. For example, approximately $2 \%$ of the articles related to the tsunami published by the newspapers under consideration focused on the response by private donors, suggesting the existence of reverse causality. In terms of omitted variable bias, other media coverage of the disaster (including cable television news, additional newspapers, Internet news coverage, and other media) may also influence donations. Similarly, some relief agencies purchased advertising and/or undertook direct mail campaigns during this period, while others were mentioned in the media specifically for their assistance to tsunami victims. Each of these occurrences may result in increased Internet donations, leading to upward-biased estimates of our measures of media coverage. Fortunately, these problems may be addressed using instrumental variables estimation.

Two different instrumental variables are separately employed in this analysis - daily media coverage of the Iraq war and the daily number of casualties among U.S. military personnel in Iraq in the 100 days following the tsunami disaster. These instruments are strong predictors of daily television news coverage of the tsunami disaster as indicated by the first stage tobit results presented in Table 4. They are also plausibly exogenous to tsunami-related donations. Regressing total time dedicated to the tsunami on time dedicated to the Iraq war while controlling for all of the other regressors in Equation 1 yields a robust z-statistic of 19.10 (Column 1), easily meeting the criteria for strong instrumental variables (Bound, Jaeger, and Baker 1995; Murray 2005; Stock and Yogo 2005). The number of casualties among U.S. military personnel is also strong (albeit considerably weaker than the previous instrument), with a robust z-statistic of 6.12 (Column 2). Finally, although both media coverage of the Iraq war and the number of U.S. military casualties in Iraq influence newspaper coverage of the tsunami disaster, neither is sufficiently strong in the first stage to yield unbiased estimates in the second 
stage, possibly because newspapers are less constrained in the number of stories covered on any given day than is broadcast news. Thus, the estimates which include instrumental variables will focus only television coverage of the tsunami.

Table 5 describes the effect of television coverage of the tsunami disaster on private donations to relief agencies using IV tobit estimation to control for any extant simultaneity and omitted variable bias. As above, private donations to relief agencies are expressed in terms of zscores and heteroskedasticity-robust standard errors are reported. Column 1 presents results that employ daily television coverage of the Iraq war as the instrument and Column 2 presents results that use the number of U.S. military casualties in Iraq by day as the instrument. The estimated effect of nightly news coverage is essentially unchanged from the tobit results without instrumentation presented in Table 1: an additional minute of television news coverage raises donations to relief agencies by between 0.036 and 0.038 standard deviations from the mean, or between $13.2 \%$ and $13.9 \%$. The estimates are significant at the $10 \%$ level when using U.S. military casualties in Iraq as the instrument and at the 1\% level when using television coverage of the Iraq war as an instrument. These results suggest that neither simultaneity bias nor omitted variable bias is a serious problem, and the subsequent results do not include instrumentation.

Finally, Table 6 includes media-agency interaction terms to determine whether the marginal effect of media coverage differs for each relief agency using tobit estimation. Again, private donations to relief agencies are expressed in terms of z-scores and heteroskedasticityrobust standard errors are reported. The estimated effect of television news coverage is not statistically different from zero for either Agency 1 or Agency 6 (Column 1), suggesting that variation in television coverage does not have any discernable effect on donations received during the study period. By contrast, an additional minute of broadcast news coverage increases donations to Agency 2 by 0.056 standard deviations $\left(\mathrm{P}>\chi^{2}=0.001\right)$, to Agency 3 by 0.082 standard deviations $\left(\mathrm{P}>\chi^{2}=0.000\right)$, to Agency 5 by 0.084 standard deviations $\left(\mathrm{P}>\chi^{2}=0.000\right)$, to Agency 7 by 0.009 standard deviations $\left(\mathrm{P}>\chi^{2}=0.038\right)$, and to Agency 8 by 0.048 standard deviations $\left(\mathrm{P}>\chi^{2}=0.083\right)$. Notably, additional television news reduces donations to Agency 4 by 0.012 standard deviations $\left(\mathrm{P}>\chi^{2}=0.089\right)$, suggesting that charitable giving may became more concentrated during the tsunami. This may occur, for example, if television coverage induces donors who have given to Agency 4 previously to donate to another agency instead. 
Similar results are found for newspaper coverage (Column 2). The marginal effect of additional coverage of the tsunami in the New York Times and the Wall Street Journal are to increase donations to Agency 2 by 0.010 standard deviations $\left(\mathrm{P}>\chi^{2}=0.010\right.$ ), to Agency 3 by 0.015 standard deviations $\left(\mathrm{P}>\chi^{2}=0.000\right)$, to Agency 5 by 0.015 standard deviations $\left(\mathrm{P}>\chi^{2}=\right.$ $0.008)$, and Agency 8 by 0.011 standard deviations $\left(P>\chi^{2}=0.098\right)$. The marginal effect of media coverage on donations to Agencies 1 and 6 is again statistically indistinguishable from zero, as is the effect of media coverage on donations to Agency 4. Interestingly, newspaper coverage of the tsunami has the opposite effect of television coverage for Agency 7, with an additional 100 words reducing estimated donations by 0.003 standard deviations $\left(\mathrm{P}>\chi^{2}=0.053\right)$, suggesting that the source of information is also important for some relief agencies.

Together, these results show that both television and newspaper coverage of the 2004 tsunami had a positive and significant effect on Internet donations to relief agencies. However, the effect varies greatly by agency, and media coverage can lead to lower donations in some cases.

\section{CONCLUSION}

This paper investigates the empirical relationship between media coverage of humanitarian crises and private donations to relief agencies. The 2004 tsunami provides an excellent case study because it prompted unprecedented media coverage, unprecedented charitable giving, and a great deal of speculation about the relationship between the two.

We assess the effects of tsunami-related reporting on $A B C$ World News Tonight, the CBS Evening News, and NBC Nightly News and tsunami-related articles in the New York Times and the Wall Street Journal on donations to eight U.S. charities that provided services to victims of the tsunami. Because Internet donations played an important role in facilitating giving after the tsunami, because they are more likely to reflect contemporaneous media coverage of the disaster, and because they are not subject to recall bias, we exclude other forms of giving in the analysis. We also control for donor fatigue via a variable measuring the number of days after the tsunami that donations were made, for tax incentives via a dummy indicating the last day that donations were eligible for 2004 deductions, and for agency-specific effects via a series of dummies.

We find that an additional minute allocated to tsunami coverage on the evening news increases that day's donations by 0.036 standard deviations from the mean, or $13.2 \%$ for the 
average agency. Similarly, 100 additional words allocated to tsunami coverage in major newspapers increase that day's donations by 0.007 standard deviations from the mean, or $2.6 \%$ for the average agency; a typical 700 -word article thus raises donations by $18.2 \%$ on average.

Simultaneity concerns may arise due to media coverage of donors' generosity. Similarly, omitted variables such as news coverage of the tsunami in other media sources, advertising, and direct mail campaigns undertaken by relief agencies may bias the estimated effect of media coverage upward. To account for this possibility, we employ two different instrumental variables - media coverage of the Iraq war and U.S. military casualties in Iraq. These instruments are strong predictors of television news coverage while remaining plausibly exogenous to donations to relief agencies, yet instrumenting for media coverage of the tsunami does not appreciably affect the point estimates.

Next, we find that the marginal effect of media coverage differs considerably among the eight agencies. For example, an additional minute of tsunami coverage on the evening news increases donations by 0.084 standard deviations for one agency while 100 additional words of tsunami coverage in newspaper articles increases donations by 0.015 standard deviations. By contrast, a different agency did not see any impact of news coverage on its Internet donations. Also, television coverage increased donations while newspaper coverage decreased donations for one agency, suggesting that the form of media coverage may also impact Internet donations for some charitable organizations.

Finally, we find that donations decay over time, even controlling for media coverage of the tsunami, providing evidence of donor fatigue. However, the Tsunami Disaster Aid Tax Relief Act, which extended tax deductions for tax year 2004 until 31 January 2005 for tsunamirelated charitable contributions, prolonged high levels of giving and contributed to record giving. This result provides further evidence that tax policy complements media coverage in inducing donations to charities.

From the perspective of economic theory, U.S. residents donating to victims half a world away provides further evidence for Andreoni's $(1989,1990)$ "warm glow" motivation for individual altruism. Because most Internet donations are unheralded, it further appears that many donors to tsunami relief were neither motivated by conspicuous giving for socioeconomic recognition (Glazer and Konrad 1996) nor by opportunities to partake in "impact philanthropy" 
(Duncan 2004). Instead, people may have participated in charitable giving at these record levels precisely because so many others were also giving (Sugden, 1984).

From a broader social perspective, our results clearly demonstrate the causal impact of media coverage of humanitarian crises on charitable giving. This conclusion suggests that encouraging media to keep humanitarian crises in the news is in the best interest of relief agencies. Media-savvy charities have certainly done so by making themselves available for updates long after disasters struck. For example, relief workers from Oxfam provided commentary about tsunami clean-up on all three network evening news broadcasts at the end of March 2005. Similarly, reconstruction efforts undertaken by Catholic Relief Services in Banda Aceh were featured in a three-minute segment on NBC Nightly News a year after the tsunami struck. Indeed, some humanitarian agencies even create news, as did the International Rescue Committee in awarding its Freedom Award to Presidents Bush and Clinton for their efforts on behalf of tsunami victims, which pushed the tsunami back into the news in mid-November 2005.

It is our hope that the television and newspaper media will also recognize this relationship and that the beneficiaries of relief agencies' efforts will enter into their calculus when deciding which news stories to present. In this way, celebrity trials may no longer push disasters out of the media spotlight. 


\section{REFERENCES}

Andreoni, James. 1989. Giving with impure altruism: Applications to charity and Ricardian equivalence. Journal of Political Economy 97(6): 1447-1458.

Andreoni, James. 1990. Impure altruism and donations to public goods: A theory of warm-glow giving. Economic Journal 100(401): 464-477.

Arrow, Kenneth. 1972. Gifts and exchanges. Philosophy and Public Affairs 1(4): 343-362.

Auten, Gerald R., Sieg, Holger, and Charles T. Clotfelter. 2002. Charitable giving, income, and taxes: An analysis of panel data. American Economic Review 92(1): 371-382.

Bound, John, David Jaeger, and Regina Baker. 1995. Problems with instrumental variables estimation when the correlation between the instruments and the endogenous explanatory variable is weak. Journal of the American Statistical Association 90(430): 443-450.

Breeze, Beth. 2005. Research review. Charity Times. 12 July.

CARMA International. 2005. The CARMA Report on Western Media Coverage of Humanitarian Disasters. January.

Clotfelter, Charles T. 1985. Federal Tax Policy and Charitable Giving. Chicago: University of Chicago Press.

Cooperman, Alan, and Jaqueline Salmon. 2005. Charities report record donations: \$337 million in private funds raised for relief. Washington Post. 8 January.

Duncan, Brian. 2004. A theory of impact philosophy. Journal of Public Economics 88: 21592180.

Eldridge, Christopher. 2005. The tsunami, the Internet and funding for forgotten emergencies. Humanitarian Exchange 30: 39-41.

El Nasser, Haya. 2005. Poll: U.S. donations still flowing to Asia. USA Today. 1 January.

Falk, Armin. 2004. Charitable giving as a gift exchange: Evidence from a field experiment. CEPR Discussion Paper No. 4189. January.

Glazer, Amahai, and Kai A. Konrad. 1996. A signaling explanation for charity. American Economic Review 84(4): 1019-1028.

Greene, Pamela, and Robert McClelland. 2001. Taxes and charitable giving. National Tax Journal 54(September); 433-453. 
Hall, C. Michael, and Steven Page. 2000. Tourism in South and Southeast Asia. Oxford: Butterworth-Heinemann.

Hall, Holly, Leah Kerkman, and Cassie J. Moore. 2005. Giving bounces back. Chronicle of Philanthropy. October 27.

Kingma, Bruce Robert. 1989. An accurate measurement of the crowd-out effect, income effect, and price effect for charitable donations. Journal of Political Economy 97(5): 1197-1207.

Murray, Michael P. 2005. The bad, the weak, and the ugly: Avoiding the pitfalls of instrumental variables estimation. Working Paper, Bates College, Lewiston, ME.

Newspaper Association of America. 2006. Top 50+ newspapers reporting to ABC. 8 May. Accessed 25 June 2006. Available at http:// www.naa.org/nadbase/top50reporting.html.

Olsen, Gorm Rye., Nils Carstensen, and Kristian Høyen. 2002. Humanitarian crises: What determines the level of emergency assistance? Disasters 27(2): 109-126.

Pew Research Center for the People and the Press. 2004. Pew Research Center biennial news consumption survey. 8 June. Accessed: 26 June 2005. Available at http://peoplepress.org/reports/pdf/215.pdf.

Ribar, David C., and Mark O. Wilhelm. 1985. Charitable contributions to international relief and development. National Tax Journal 48(2): 229-244.

Robinson, Piers. 2002. The CNN effect: The myth of news, foreign policy and intervention. London: Routledge.

Rose-Ackerman, Susan. 1982. Charitable giving and "excessive" fundraising. Quarterly Journal of Economics 97(2): 193-212.

Rose-Ackerman, Susan. 1996. Altruism, nonprofits, and economic theory. Journal of Economic Literature 34: 701-728,

Slavin, Barbara. 2004. Rush of donations from USA is immediate and immense. USA Today, 30 December.

Slemrod, Joel. 1989. Are estimated tax elasticities really just tax evasion elasticities? The case of chariable contributions. Review of Economics and Statistics 71(3): 517-522.

Steinberg, Richard. 1987. Voluntary donations and public expenditures in a federalist system. American Economic Review 77(1): 24-36.

Steinberg, Richard, and Mark Wilhelm. 2003. Tracking giving across generations. New Directions for Philanthropic Fundraising 42: 71-82. 
Stock, James H,. and Motohiro Yogo. 2005. Testing for weak instruments in linear IV regression. Ch. 5 in James H. Stock, and Donald W.K. Andrews, eds, Identification and Inference for Econometric Models: A Festschrift in Honor of Thomas Rothenberg. Cambridge: Cambridge University Press, 80-108.

Strom, Stephanie. 2004. Tsunami followed by another kind of flood: U.S. citizens' dollars. New York Times, 30 December.

Strom, Stephanie. 2005. Relief groups hail level of donations by individuals. New York Times, 1 January.

Sugden, Robert. 1984. Reciprocity: The supply of public goods through voluntary contributions. Economic Journal 94(376): 772-787.

UN Office of the Special Envoy for Tsunami Recovery. 2005. Country fact sheets: The human toll. 8 November. Accessed 25 June 2006. Available at http://www.tsunamispecialenvoy.org/country/humantoll.asp.

Wallace, Nicole, and Ian Wilhelm. 2005. A year of progress, s year of setbacks. Chronicle of Philanthropy. December 8.

Wynter, Alex. 2005. Humanitarian media coverage in the digital age. Ch. 6 in Red Cross Red Crescent World Disasters Report 2005. Broomfield, CT: Kumarian Press Inc, 126-149. 
TABLE 1

Summary Statistics

\begin{tabular}{lcrrrrr} 
Variable & Unit & Obs. & \multicolumn{1}{c}{ Mean } & Std. Dev. & Min. & \multicolumn{1}{c}{ Max. } \\
\hline Total Internet & & & & & & \\
Donations & $\#$ & 714 & $\$ 72,583.30$ & $\$ 265,802.00$ & $\$ 0.00$ & $\$ 3,145,853.00$ \\
Donations to Agency 1 & $\#$ & 101 & $\$ 171.60$ & $\$ 556.96$ & $\$ 0.00$ & $\$ 5,000.00$ \\
Donations to Agency 2 & $\#$ & 101 & $\$ 106,561.60$ & $\$ 287,211.00$ & $\$ 1,143.00$ & $\$ 1,968,930.00$ \\
Donations to Agency 3 & $\#$ & 101 & $\$ 126,914.90$ & $\$ 357,153.40$ & $\$ 0.00$ & $\$ 2,004,113.00$ \\
Donations to Agency 4 & $\#$ & 71 & $\$ 3,515.61$ & $\$ 12,530.91$ & $\$ 0.00$ & $\$ 98,346.22$ \\
Donations to Agency 5 & $\#$ & 98 & $\$ 135,070.50$ & $\$ 389,883.50$ & $\$ 1,773.00$ & $\$ 2,896,813.00$ \\
Donations to Agency 6 & $\#$ & 101 & $\$ 23,735.52$ & $\$ 59,864.76$ & $\$ 0.00$ & $\$ 392,857.60$ \\
Donations to Agency 7 & $\#$ & 71 & $\$ 964.16$ & $\$ 1,660.80$ & $\$ 0.00$ & $\$ 9,560.00$ \\
Donations to Agency 8 & $\#$ & 70 & $\$ 175,339.40$ & $\$ 403,689.70$ & $\$ 1,670.00$ & $\$ 3,145,853.00$ \\
ABC Daily Minutes & $\#$ & 101 & 1.88 & 4.02 & 0.00 & 18.00 \\
CBS Daily Minutes & $\#$ & 101 & 1.52 & 3.17 & 0.00 & 12.67 \\
NBC Daily Minutes & $\#$ & 101 & 2.23 & 4.11 & 0.00 & 14.83 \\
Total Daily TV Minutes & $\#$ & 101 & 5.63 & 10.42 & 0.00 & 39.00 \\
NYT Daily Word Count & $\#$ & 101 & $1,791.85$ & $2,745.96$ & 0.00 & $15,132.00$ \\
WSJ Daily Word Count & $\#$ & 73 & $2,356.27$ & $3,644.75$ & 0.00 & $14,888.00$ \\
Total Daily Word & & & & & & \\
Count & $\#$ & 101 & $3,494.90$ & $5,642.75$ & 0.00 & $30,020.00$
\end{tabular}


TABLE 2

Effect of Nightly News Coverage on Donations to Relief Agencies (z-scores)

(Tobit)

\begin{tabular}{|c|c|c|c|c|}
\hline & $\begin{array}{l}(1) \\
\text { Total }\end{array}$ & $\begin{array}{c}(2) \\
A B C\end{array}$ & $\begin{array}{c}(3) \\
\text { CBS }\end{array}$ & $\begin{array}{c}(4) \\
\text { NBC }\end{array}$ \\
\hline Coverage on Nightly News (Minutes) & $\begin{array}{l}0.035^{\star \star \star} \\
(5.32)\end{array}$ & $\begin{array}{l}0.084^{\star \star \star} \\
(4.81)\end{array}$ & $\begin{array}{l}0.060^{\star \star \star} \\
(3.49)\end{array}$ & $\begin{array}{l}0.065^{\star \star \star} \\
(4.76)\end{array}$ \\
\hline Log Days After & $\begin{array}{l}-0.351^{* * *} \\
(4.15)\end{array}$ & $\begin{array}{l}-0.412^{\star \star *} \\
(5.03)\end{array}$ & $\begin{array}{l}-0.531^{\star \star *} \\
(5.62)\end{array}$ & $\begin{array}{l}-0.450^{\star \star \star} \\
(4.81)\end{array}$ \\
\hline Dummy for 31 January & $\begin{array}{l}0.659^{\star \star \star} \\
(3.05)\end{array}$ & $\begin{array}{l}0.616^{\star \star \star} \\
(2.87)\end{array}$ & $\begin{array}{l}0.555^{\star \star \star} \\
(2.58)\end{array}$ & $\begin{array}{l}0.601^{\star \star \star} \\
(2.82)\end{array}$ \\
\hline Agency 2 & $\begin{array}{l}1.143^{\star \star *} \\
(6.56)\end{array}$ & $\begin{array}{l}1.140^{* \star \star} \\
(6.54)\end{array}$ & $\begin{array}{l}1.167^{\star \star \star} \\
(6.64)\end{array}$ & $\begin{array}{l}1.161^{\star \star *} \\
(6.58)\end{array}$ \\
\hline Agency 3 & $\begin{array}{l}1.106^{\star \star \star} \\
(6.00)\end{array}$ & $\begin{array}{l}1.103^{\star \star \star} \\
(6.01)\end{array}$ & $\begin{array}{l}1.122^{\star \star \star} \\
(6.00)\end{array}$ & $\begin{array}{l}1.118^{\star \star \star} \\
(5.98)\end{array}$ \\
\hline Agency 4 & $\begin{array}{l}0.210 \\
(1.38)\end{array}$ & $\begin{array}{l}0.198 \\
(1.30)\end{array}$ & $\begin{array}{l}0.210 \\
(1.45)\end{array}$ & $\begin{array}{l}0.235 \\
(1.60)\end{array}$ \\
\hline Agency 5 & $\begin{array}{l}1.266^{\star \star *} \\
(5.84)\end{array}$ & $\begin{array}{l}1.264^{* * *} \\
(5.84)\end{array}$ & $\begin{array}{l}1.293^{\star * *} \\
(5.86)\end{array}$ & $\begin{array}{l}1.285^{\star \star \star} \\
(5.85)\end{array}$ \\
\hline Agency 6 & $\begin{array}{l}0.778^{\star \star \star} \\
(5.17)\end{array}$ & $\begin{array}{l}0.775^{\star \star \star} \\
(5.13)\end{array}$ & $\begin{array}{l}0.800^{* * *} \\
(5.38)\end{array}$ & $\begin{array}{l}0.794^{\star \star *} \\
(5.30)\end{array}$ \\
\hline Agency 7 & $\begin{array}{l}1.024^{\star \star \star} \\
(5.84)\end{array}$ & $\begin{array}{l}1.011^{* * *} \\
(5.80)\end{array}$ & $\begin{array}{l}1.039 \text { *** } \\
(5.91)\end{array}$ & $\begin{array}{l}1.041^{\text {*** }} \\
(5.90)\end{array}$ \\
\hline Agency 8 & $\begin{array}{l}1.360^{\star \star \star *} \\
(5.45)\end{array}$ & $\begin{array}{l}1.351^{* * \star} \\
(5.41)\end{array}$ & $\begin{array}{l}1.383^{\star * \star} \\
(5.53)\end{array}$ & $\begin{array}{l}1.396^{\star \star *} \\
(5.54)\end{array}$ \\
\hline Constant & $\begin{array}{l}0.027 \\
(0.09)\end{array}$ & $\begin{array}{l}0.296 \\
(1.12)\end{array}$ & $\begin{array}{l}0.761^{\star \star} \\
(2.55)\end{array}$ & $\begin{array}{l}0.423 \\
(1.39)\end{array}$ \\
\hline Observations & 709 & 709 & 709 & 709 \\
\hline
\end{tabular}

NOTE: Absolute value of robust z-statistics in parentheses.

* significant at 10\%; ** significant at 5\%; *** significant at $1 \%$ 
TABLE 3

Effect of Newspaper Coverage on Donations to Relief Agencies (z-scores)

(Tobit)

\begin{tabular}{|c|c|c|c|}
\hline & $\begin{array}{c}(1) \\
\text { Total }\end{array}$ & $\begin{array}{c}(2) \\
\text { NYT }\end{array}$ & $\begin{array}{c}(3) \\
\text { WSJ }\end{array}$ \\
\hline Newspaper Word Count (100 Words) & $\begin{array}{l}0.0071^{\star \star \star} \\
(3.61)\end{array}$ & $\begin{array}{l}0.0096^{* \star *} \\
(3.05)\end{array}$ & $\begin{array}{l}0.0138^{\star \star \star} \\
(3.71)\end{array}$ \\
\hline Log Days After & $\begin{array}{l}-0.353^{\star \star \star} \\
(4.11)\end{array}$ & $\begin{array}{l}-0.493^{\star \star \star} \\
(5.30)\end{array}$ & $\begin{array}{l}-0.321^{\star \star \star} \\
(3.06)\end{array}$ \\
\hline Dummy for 31 January & $\begin{array}{l}0.674^{\star \star \star} \\
(3.00)\end{array}$ & $\begin{array}{l}0.565^{\star \star \star} \\
(2.62)\end{array}$ & $\begin{array}{l}0.773^{\star \star \star} \\
(3.23)\end{array}$ \\
\hline Agency 2 & $\begin{array}{l}1.166^{* \star *} \\
(6.81)\end{array}$ & $\begin{array}{l}1.184^{\star \star *} \\
(6.73)\end{array}$ & $\begin{array}{l}1.331^{* \star *} \\
(6.48)\end{array}$ \\
\hline Agency 3 & $\begin{array}{l}1.126^{\star \star \star} \\
(6.12)\end{array}$ & $\begin{array}{l}1.137^{\star \star \star} \\
(6.06)\end{array}$ & $\begin{array}{l}1.327^{\star \star \star} \\
(5.84)\end{array}$ \\
\hline Agency 4 & $\begin{array}{l}0.183 \\
(1.21)\end{array}$ & $\begin{array}{l}0.236^{*} \\
(1.65)\end{array}$ & $\begin{array}{l}0.285 \\
(1.62)\end{array}$ \\
\hline Agency 5 & $\begin{array}{l}1.281^{* * *} \\
(6.08)\end{array}$ & $\begin{array}{l}1.302^{\star * *} \\
(6.00)\end{array}$ & $\begin{array}{l}1.453^{\star * \star} \\
(5.64)\end{array}$ \\
\hline Agency 6 & $\begin{array}{l}0.802^{* * *} \\
(5.40)\end{array}$ & $\begin{array}{l}0.817^{\star * \star} \\
(5.48)\end{array}$ & $\begin{array}{l}0.889^{* * *} \\
(4.99)\end{array}$ \\
\hline Agency 7 & $\begin{array}{l}1.064^{\star \star \star} \\
(6.05)\end{array}$ & $\begin{array}{l}1.081^{* \star *} \\
(6.00)\end{array}$ & $\begin{array}{l}1.210^{\star \star \star} \\
(5.80)\end{array}$ \\
\hline Agency 8 & $\begin{array}{l}1.359^{\star \star \star} \\
(5.82)\end{array}$ & $\begin{array}{l}1.420^{\star \star \star} \\
(5.76)\end{array}$ & $\begin{array}{l}1.496^{\star \star \star} \\
(5.78)\end{array}$ \\
\hline Constant & $\begin{array}{l}-0.045 \\
(0.12) \\
\end{array}$ & $\begin{array}{l}0.522 \\
(1.51)\end{array}$ & $\begin{array}{l}-0.336 \\
(0.73) \\
\end{array}$ \\
\hline $\begin{array}{l}\text { Observations } \\
\text { Censored Observations }\end{array}$ & $\begin{array}{l}709 \\
118\end{array}$ & 709 & 554 \\
\hline
\end{tabular}

NOTE: Absolute value of robust $z$-statistics in parentheses

${ }^{*}$ significant at $10 \%$; ** significant at $5 \%$; ${ }^{* \star *}$ significant at $1 \%$ 
TABLE 4

Effect of Iraq News Coverage and U.S. Military Casualties on Tsunami Coverage During Evening News Broadcasts

(First Stage of IV Tobit)

\begin{tabular}{|c|c|c|}
\hline & $\begin{array}{c}(1) \\
\text { Iraq News } \\
\text { Coverage }\end{array}$ & $\begin{array}{c}(2) \\
\text { US Military } \\
\text { Casualties }\end{array}$ \\
\hline Coverage on Nightly News (Minutes) & $\begin{array}{l}-0.286^{\star \star \star} \\
(19.10)\end{array}$ & $\begin{array}{l}-0.191^{\star \star \star} \\
(6.12)\end{array}$ \\
\hline Log Days After & $\begin{array}{l}-9.302^{\star \star \star} \\
(34.22)\end{array}$ & $\begin{array}{l}-9.264^{\star \star \star} \\
(31.82)\end{array}$ \\
\hline Dummy for 31 January & $\begin{array}{l}2.396^{\star \star \star} \\
(5.27)\end{array}$ & $\begin{array}{l}-5.682^{\star \star \star} \\
(22.77)\end{array}$ \\
\hline Agency 2 & $\begin{array}{l}0.000 \\
(0.00)\end{array}$ & $\begin{array}{l}0.000 \\
(0.00)\end{array}$ \\
\hline Agency 3 & $\begin{array}{l}0.000 \\
(0.00)\end{array}$ & $\begin{array}{l}0.000 \\
(0.00)\end{array}$ \\
\hline Agency 4 & $\begin{array}{l}0.340 \\
(0.40)\end{array}$ & $\begin{array}{l}0.391 \\
(0.43)\end{array}$ \\
\hline Agency 5 & $\begin{array}{l}0.091 \\
(0.12)\end{array}$ & $\begin{array}{l}0.083 \\
(0.10)\end{array}$ \\
\hline Agency 6 & $\begin{array}{l}0.000 \\
(0.00)\end{array}$ & $\begin{array}{l}0.000 \\
(0.00)\end{array}$ \\
\hline Agency 7 & $\begin{array}{l}-0.350 \\
(0.50)\end{array}$ & $\begin{array}{l}-0.524 \\
(0.70)\end{array}$ \\
\hline Agency 8 & $\begin{array}{l}0.340 \\
(0.40)\end{array}$ & $\begin{array}{l}0.391 \\
(0.43)\end{array}$ \\
\hline Constant & $\begin{array}{l}41.643^{* * *} \\
(34.01)\end{array}$ & $\begin{array}{l}39.597^{\star * *} \\
(30.75)\end{array}$ \\
\hline $\begin{array}{l}\text { Observations } \\
\text { Censored Observations }\end{array}$ & $\begin{array}{l}800 \\
440\end{array}$ & 800 \\
\hline
\end{tabular}

NOTE: Absolute value of robust z-statistics in parentheses

* significant at 10\%; ** significant at 5\%; *** significant at $1 \%$ 
TABLE 5

Effect of Television Coverage on Donations to Relief Agencies (z-scores) with Instrumental Variables

(Second Stage of IV Tobit)

(1)

(2)

Iraq News US Military

Coverage Casualties

Coverage on Nightly News (Minutes)

$0.038^{\star \star *} \quad 0.036^{\star}$

Log Days After

(3.32) (1.65)

$-0.311^{\star \star *} \quad-0.333^{*}$

Dummy for 31 January

(4.75) (1.95)

$0.646^{\star \star \star} \quad 0.632^{\star \star \star}$

Agency 2

(2.94) (2.58)

$1.035^{\star \star \star} \quad 1.035^{\star \star \star}$

(6.04) (6.02)

Agency 3

$1.031^{* \star *} \quad 1.032^{\text {***}}$

(5.68) (5.67)

Agency 4

$0.186 \quad 0.186$

Agency 5

(1.25) (1.27)

$1.158^{\star \star *} \quad 1.158^{\star \star \star}$

(5.42) $\quad 5.40$

Agency 6

$0.681^{\star \star \star} \quad 0.681^{\star \star \star}$

Agency 7

(4.61) $\quad 4.61$

$0.916^{\star \star \star} \quad 0.915^{\star \star \star}$

Agency 8

(5.26) $\quad 5.21$

\begin{tabular}{lll} 
Agency 8 & $1.251^{\star \star \star}$ & $1.253^{\star \star \star}$ \\
Constant & $(5.12)$ & 5.11 \\
& -0.024 & 0.069 \\
& $(0.08)$ & $(0.09)$ \\
\hline Observations & 709 & 709 \\
Censored Observations & 118 &
\end{tabular}

NOTE: Absolute value of robust z-statistics in parentheses

* significant at 10\%; ** significant at 5\%; ${ }^{* \star}$ significant at $1 \%$ 


\section{TABLE 6}

Effect of Media Coverage on Donations to Each Relief Agency (z-scores)

(Tobit)

\begin{tabular}{|c|c|c|}
\hline & Television & Newspaper \\
\hline Media Coverage (Minutes or Word Counts) & $\begin{array}{l}-0.0055 \\
(0.87)\end{array}$ & $\begin{array}{l}0.00060 \\
(0.56)\end{array}$ \\
\hline Log Days After & $\begin{array}{l}-0.3133^{\star \star \star} \\
(3.99)\end{array}$ & $\begin{array}{l}-0.3255^{\star \star \star} \\
(4.03)\end{array}$ \\
\hline Dummy for 31 January & $\begin{array}{l}0.6149^{\star * *} \\
(2.74)\end{array}$ & $\begin{array}{l}0.6253^{\star \star \star} \\
(2.64)\end{array}$ \\
\hline Agency 2 & $\begin{array}{l}0.6274^{\star \star \star} \\
(4.79)\end{array}$ & $\begin{array}{l}0.6572^{\star \star \star} \\
(4.67)\end{array}$ \\
\hline Agency 3 & $\begin{array}{l}0.4519^{\star \star \star} \\
(3.82)\end{array}$ & $\begin{array}{l}0.4589^{\star \star \star} \\
(3.39)\end{array}$ \\
\hline Agency 4 & $\begin{array}{l}0.2236^{\star \star} \\
(2.24)\end{array}$ & $\begin{array}{l}0.2376^{\star \star} \\
(2.14)\end{array}$ \\
\hline Agency 5 & $\begin{array}{l}0.6087^{\star \star *} \\
(4.81)\end{array}$ & $\begin{array}{l}0.6090^{\star \star \star} \\
(4.25)\end{array}$ \\
\hline Agency 6 & $\begin{array}{l}0.6057^{\star \star *} \\
(4.83)\end{array}$ & $\begin{array}{l}0.6701^{\star \star \star} \\
(5.39)\end{array}$ \\
\hline Agency 7 & $\begin{array}{l}0.6343^{\star \star *} \\
(4.91)\end{array}$ & $\begin{array}{l}0.7525^{\star \star \star} \\
(5.83)\end{array}$ \\
\hline Agency 8 & $\begin{array}{l}0.8840^{\star \star *} \\
(7.12)\end{array}$ & $\begin{array}{l}0.7834^{\star \star *} \\
(5.19)\end{array}$ \\
\hline Media Coverage*Agency 2 & $\begin{array}{l}0.0616^{\star \star \star} \\
(3.56)\end{array}$ & $\begin{array}{l}0.0092^{\star \star} \\
(2.56)\end{array}$ \\
\hline Media Coverage*Agency 3 & $\begin{array}{l}0.0878^{\star \star *} \\
(4.25)\end{array}$ & $\begin{array}{l}0.0137^{\star \star *} \\
(3.62)\end{array}$ \\
\hline Media Coverage*Agency 4 & $\begin{array}{l}-0.0068 \\
(0.93)\end{array}$ & $\begin{array}{l}-0.0012 \\
(1.39)\end{array}$ \\
\hline Media Coverage*Agency 5 & $\begin{array}{l}0.0896^{\star \star *} \\
(3.63)\end{array}$ & $\begin{array}{l}0.0138^{\star \star *} \\
(2.68)\end{array}$ \\
\hline Media Coverage*Agency 6 & $\begin{array}{l}0.0005 \\
(0.08)\end{array}$ & $\begin{array}{l}-0.0012 \\
(1.14)\end{array}$ \\
\hline Media Coverage*Agency 7 & $\begin{array}{l}0.0147^{*} \\
(1.77)\end{array}$ & $\begin{array}{l}-0.0036^{\star *} \\
(2.42)\end{array}$ \\
\hline Media Coverage*Agency 8 & $\begin{array}{l}0.0531 * \\
(1.89)\end{array}$ & $\begin{array}{l}0.0104^{*} \\
(1.69)\end{array}$ \\
\hline Constant & $\begin{array}{l}0.2931 \\
(1.04)\end{array}$ & $\begin{array}{l}0.2621 \\
(0.81)\end{array}$ \\
\hline Observations & 709 & 709 \\
\hline Censored Observations & 118 & \\
\hline
\end{tabular}


FIGURE 1

Donations and Television Coverage from Day 0 to Day 21

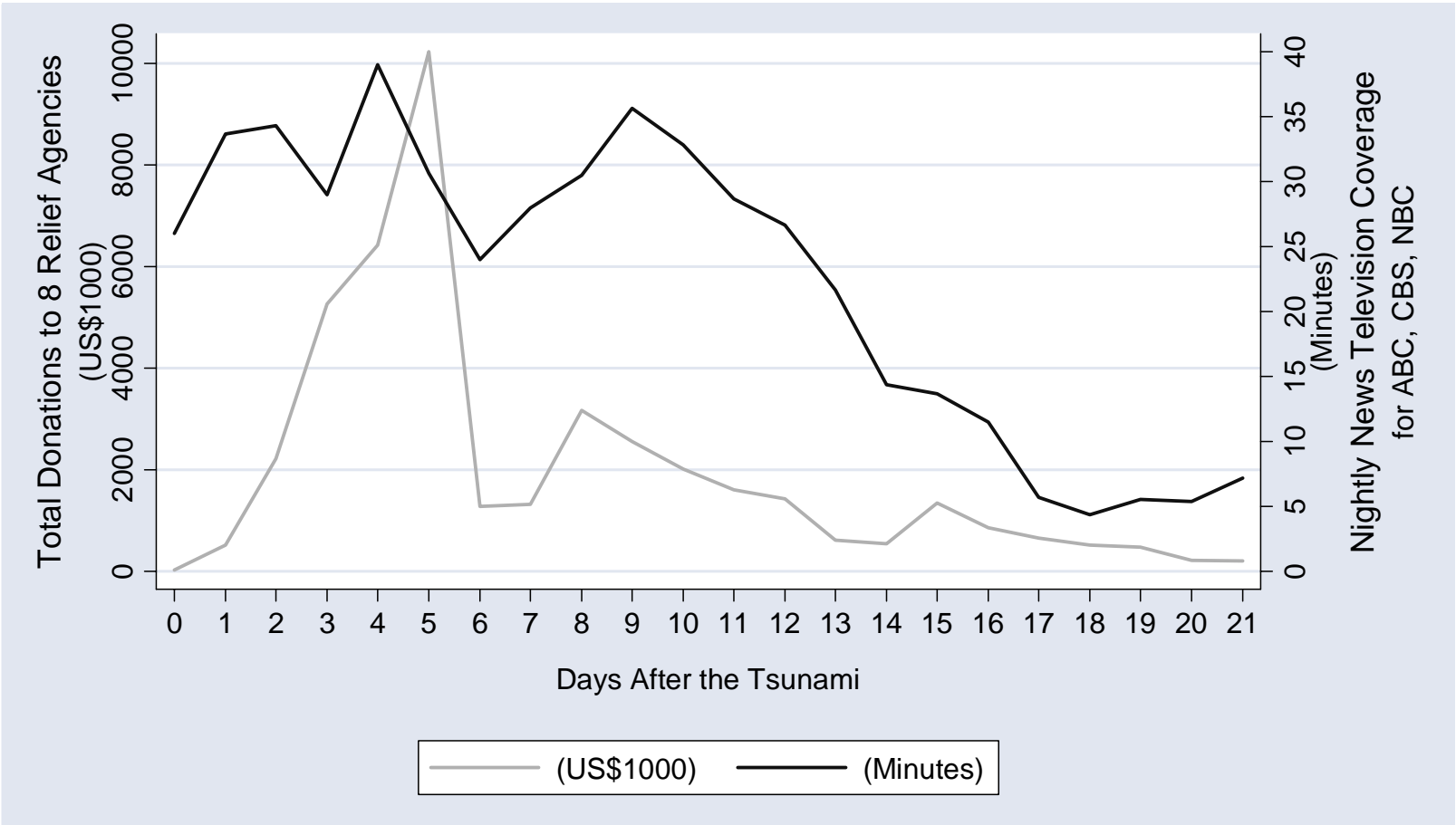


FIGURE 2

Donations and Television Coverage from Day 21 to Day 100

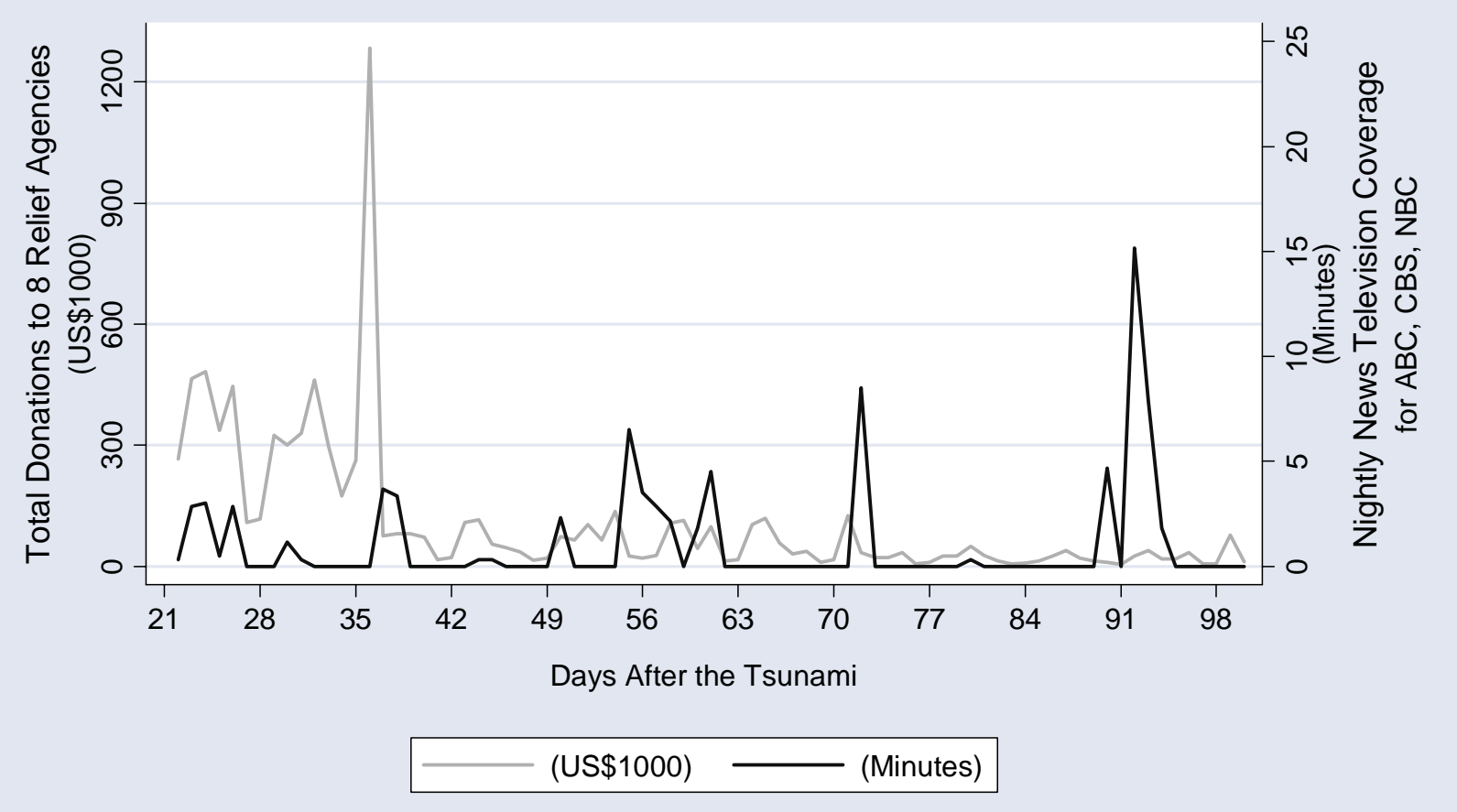


FIGURE 3

Newspaper and Television Coverage from Day 0 to Day 100

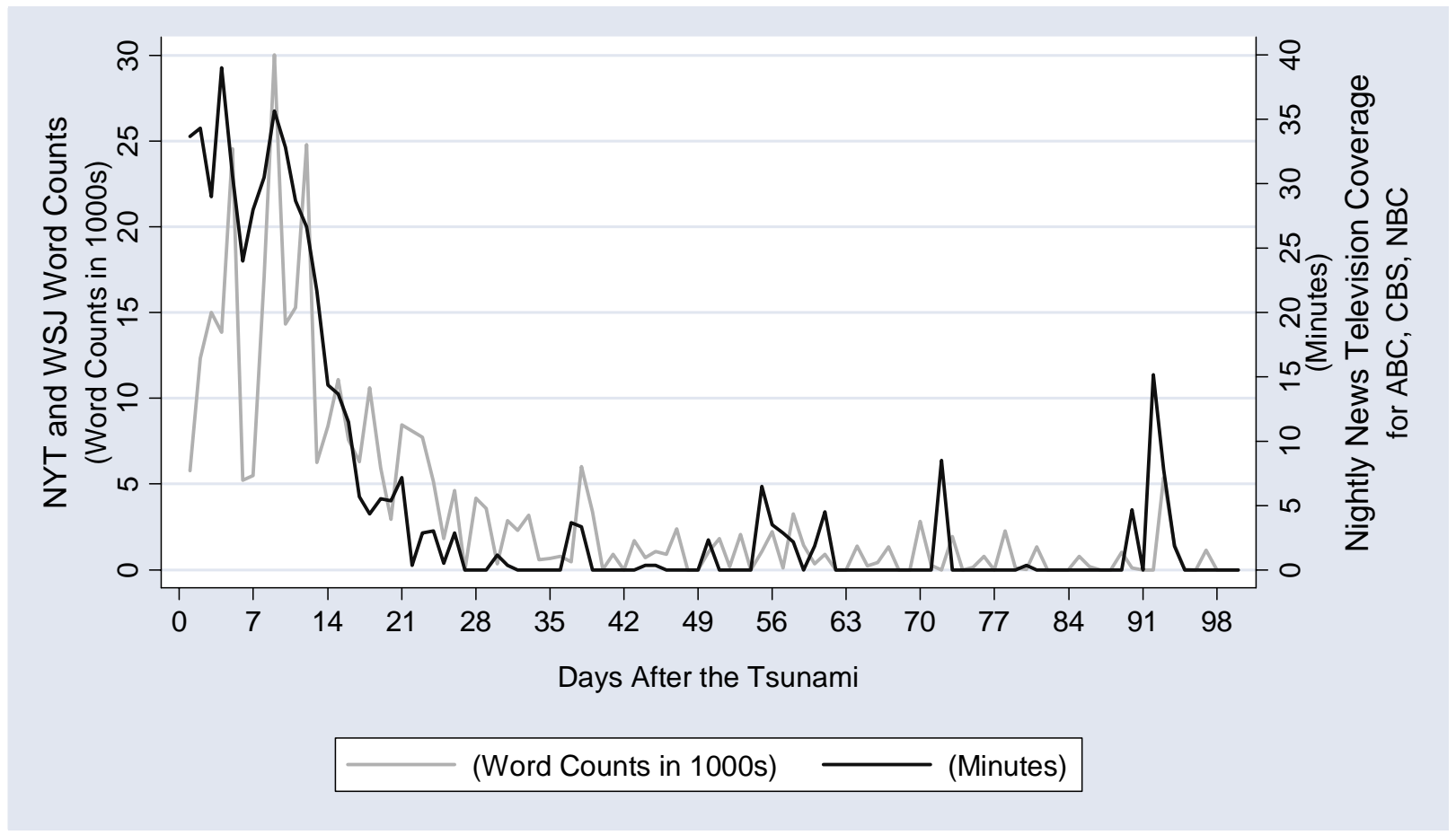




\section{Media Coverage and Charitable Giving After the 2004 Tsunami}

Philip H. Brown \& Jessica H. Minty

\section{Executive Summary}

This paper investigates the empirical relationship between media coverage of humanitarian crises and private donations to relief agencies. The 2004 tsunami provides an excellent case study because it prompted unprecedented media coverage of a humanitarian crisis, unprecedented charitable giving to relief agencies, and a great deal of speculation about the relationship between the two.

We assess the effects of tsunami-related reporting on the three network nightly news broadcasts and tsunami-related articles in two major newspapers on donations to eight U.S. charities that provided services to tsunami victims. We focus on donations made via the Internet in particular to minimize time lags between media coverage and the receipt of a donation. In order to make meaningful comparisons across all 8 agencies, we convert each day's donations to deviations from the mean daily donation. To better isolate the effect of media coverage, our analysis controls for the passage of time and for tax incentives for making charitable donations. We find:

- Media coverage of the tsunami clearly affected donations to relief agencies, even controlling for the passage of time and tax incentives. One additional minute of tsunami coverage on the evening news increases donations on that day by 0.036 standard deviations from the mean, or $13.2 \%$ for the average agency.

- One hundred additional words allocated to tsunami coverage in major newspapers increase that day's donations by 0.007 standard deviations from the mean, or $2.6 \%$ for the average agency; a typical 700 -word article thus raises donations by $18.2 \%$ on average.

- Donations decline over time, providing evidence of donor fatigue. By contrast, the Tsunami Disaster Aid Tax Relief Act prolonged high levels of giving and contributed to record giving.

Unfortunately, these results are subject to two important statistical limitations. First, while we account for time and tax incentives, we are unable to control for other aspects of charitable giving such as direct mail campaigns, advertising, and news coverage in other media. Second, the unprecedented giving occasionally became news itself, raising questions about the direction of causality between media coverage and charitable giving. To account for these possibilities, we employ an econometric method known as instrumental variables. In doing so, we find:

- Correcting for these statistical limitations does not affect the estimated effect of media coverage on charitable giving, i.e., the main results are extremely robust.

Finally, we consider the possibility that the effect of media coverage on charitable giving is not uniform across relief agencies. We find:

- While giving to most of the charities included in the study increases with media coverage, donations to some agencies were not impacted by media coverage.

These results clearly demonstrate the large, causal, impact of media coverage of humanitarian crises on charitable giving to the majority of relief agencies. We hope that this finding will enter the calculus of news media when deciding which stories to present. 


\section{DAVIDSON INSTITUTE WORKING PAPER SERIES - Most Recent Papers}

The entire Working Paper Series may be downloaded free of charge at: www.wdi.umich.edu

CURRENT AS OF $1 / 15 / 07$

\begin{tabular}{|c|c|c|}
\hline Publication & Authors & Date \\
\hline No. 855: Media Coverage \& Charitable Giving After the 2004 Tsunami & Philip Brown and Jessica Minty & Dec 2006 \\
\hline $\begin{array}{l}\text { No. 854: Default Rates in the Loan Market for SMEs: Evidence from } \\
\text { Slovakia }\end{array}$ & $\begin{array}{l}\text { Jarko Fidrmuc, Christa Hainz and } \\
\text { Anton Maleisch }\end{array}$ & Nov 2006 \\
\hline $\begin{array}{l}\text { No. 853: Monetary Policy before Euro Adoption: Challenges for EU } \\
\text { New Members }\end{array}$ & $\begin{array}{l}\text { Jan Filáček, Roman Horváth and } \\
\text { Michal Skorepa }\end{array}$ & Nov 2006 \\
\hline $\begin{array}{l}\text { No. 852: Private-Sector Credit in Central \& Eastern Europe: New } \\
\text { (Over) Shooting Stars? }\end{array}$ & $\begin{array}{l}\text { Balázs Égert, Peter Backé and } \\
\text { Tina Zumer }\end{array}$ & Nov 2006 \\
\hline $\begin{array}{l}\text { No. 851: Interest Rate Pass-Through in Central \& Eastern Europe: } \\
\text { Reborn from Ashes Merely to Pass Away? }\end{array}$ & $\begin{array}{l}\text { Balázs Égert,Jesus Crespo- } \\
\text { Cuaresma and Thomas Reininger }\end{array}$ & Nov 2006 \\
\hline $\begin{array}{l}\text { No. 850: Monetary Transmission Mechanism in Central \& Eastern } \\
\text { Europe: Gliding on a Wind of Change }\end{array}$ & $\begin{array}{l}\text { Fabrizio Coricelli, Balázs Égert } \\
\text { and Ronald MacDonald }\end{array}$ & Nov 2006 \\
\hline No. 849: Crime Distribution \& Victim behavior During a Crime Wave & $\begin{array}{l}\text { Rafael Di Tella, Sebastian Galiani } \\
\text { and Ernesto Schargrodsky }\end{array}$ & Nov 2006 \\
\hline $\begin{array}{l}\text { No. 848: Real-Time Time-Varying Equilibrium Interest Rates: Evidence } \\
\text { on the Czech Republic }\end{array}$ & Roman Horváth & Oct 2006 \\
\hline $\begin{array}{l}\text { No. 847: Financial Accelerator Effects in the Balance Sheets of Czech } \\
\text { Firms }\end{array}$ & Roman Horváth & Nov 2006 \\
\hline $\begin{array}{l}\text { No. 846: Central Bank Interventions, Communication \& Interest Rate } \\
\text { Policy in Emerging European Economies }\end{array}$ & Balázs Égert & Nov 2006 \\
\hline $\begin{array}{l}\text { No. 845: On the Role of Absorptive Capacity: FDI Matters to } \\
\text { Growth }\end{array}$ & Yuko Kinishita and Chia-Hui Lu & Nov 2006 \\
\hline No. 844: Current Account Sustainability in Selected Transition Countries & Aleksander Aristovnik & Nov 2006 \\
\hline $\begin{array}{l}\text { No. 843: Policy, Economic Federalism \& Product Market Entry: The } \\
\text { Indian Experience }\end{array}$ & $\begin{array}{l}\text { Sumon Bhaumik, Shubhashis } \\
\text { Gangopadhyay and Shagun } \\
\text { Krishnan }\end{array}$ & Nov 2006 \\
\hline No. 842: Price Mobility of Locations & Konstantin Gluschenko & Oct 2006 \\
\hline $\begin{array}{l}\text { No. 841: The Role of Foreign Direct Investment in the Firm Selection } \\
\text { Process in a Host Country: Evidence from Slovenia }\end{array}$ & Katja Zajc Kejzar & Sept 2006 \\
\hline $\begin{array}{l}\text { No. 840: Family Ownership and Control in Large Firms: The Good, The } \\
\text { Bad, The Irrelevant - and Why? }\end{array}$ & Mike Peng and Yi Jiang & Oct 2006 \\
\hline No. 839: Price Linkages of Russian Regional Markets & Konstantin Gluschenko & Sept 2006 \\
\hline $\begin{array}{l}\text { No. 838: The Effect of Pre-Primary Education on Primary School } \\
\text { Performance }\end{array}$ & $\begin{array}{l}\text { Samuel Berlinski, Sebastian } \\
\text { Galiani and Paul Gertler }\end{array}$ & July 2006 \\
\hline $\begin{array}{l}\text { No. 837: Do Investors Value Insider Trading Laws? International } \\
\text { Evidence }\end{array}$ & Laura Beny & Aug 2006 \\
\hline No. 836: How corruption Hits People When They Are Down & Jennifer Hunt & Aug 2006 \\
\hline No. 835: Mirage at the Bottom of the Pyramid & Aneel Karnani & Aug 2006 \\
\hline $\begin{array}{l}\text { No. 834: Ownership concentration and firm performance: Evidence from } \\
\text { an emerging market }\end{array}$ & Irena Grosfeld & June 2006 \\
\hline $\begin{array}{l}\text { No. 833: Institutions, Networks and Entrepreneurship Development in } \\
\text { Russia: An Exploration }\end{array}$ & Ruta Aidis and Saul Estrin & June 2006 \\
\hline $\begin{array}{l}\text { No. 832: Long \& Short Run Linkages in CEE Stock Markets: } \\
\text { Implications for Portfolio Diversification \& Stock Market Integration }\end{array}$ & $\begin{array}{l}\text { Manolis Syllignakis and Georgios } \\
\text { Kouretas }\end{array}$ & July 2006 \\
\hline
\end{tabular}

